\title{
1. Socially responsible international business: review, synthesis, and directions
}

\author{
Leonidas C. Leonidou, Constantine S. \\ Katsikeas, Saeed Samiee, and \\ Constantinos N. Leonidou
}

\subsection{INTRODUCTION}

The firm's socially responsible activities have been an issue of major academic concern since the late 1960s, with dozens of articles written on the subject. This reflects the growing challenges faced by organizations with regard to increasing criticism for causing environmental damage, engaging in unethical business practices, enforcing discrimination practices, and other irresponsible actions (Grinstein and Riefler, 2015). It also mirrors the dramatic rise in sensitivity to various social issues (e.g., climatic changes, child labor, corruption/bribery) on the part of citizens, shareholders, and other stakeholder groups, which has had serious effects on consumption, investment, and other behaviors affecting firms' activities (Demirbag et al., 2017). It further underlines the increasing tendency of governments and other parastatal organizations to demonstrate social consciousness and to adopt the close surveillance of possibly illegal business practices, such as those violating health and safety, financial transparency, and human rights (Rathert, 2016).

As opposed to extensive research on socially responsible activities among firms in a domestic context, their international business dimension has received less attention (Egri and Ralston, 2008; Pisani et al., 2017). This is paradoxical, however, because growing globalization has been the reason for an increasing number of firms to transcend national boundaries and confront various social-related issues, such as those pertaining to ethical and environmental conduct. Moreover, the widespread use of social media has put any form of anti-social business behavior by international firms on the spot, with detrimental effects on their business performance (as a 
result, for example, of buyer boycotts, reputational damage, and legalistic actions). Furthermore, the multiplicity and diversity of business environments across countries calls for a careful adjustment and refinement of the international firm's ethical, green, and other socially responsible strategies (Kolk and van Tulder, 2010).

Despite this different emphasis of scholarly research on the firm's socially responsible behavior in a domestic versus global context, a critical mass of international business studies on the subject has been accumulated over time. This has taken many different directions and produced multiple findings (Eteokleous, Leonidou, and Katsikeas, 2016; Zhao, Zhang, and Kwon, 2018). Hence, the purpose of this chapter is to review and synthesize the content of extant studies in this important field of research and establish trends concerning its evolution. Specifically, we have three major objectives to accomplish: (1) to identify the key contributing outlets and prolific authors in this line of research, as well as trace the most influential articles; (2) to assess the research design, scope of research, and study methodology employed by scholars in the field; and (3) to categorize knowledge on the subject into key thematic areas and indicate how these have evolved over time.

Such an endeavor would be beneficial for various interested parties: (a) managers, who can become more aware of the range of social challenges confronted by firms in international markets, as well as acquire useful knowledge necessary to enhance their socially responsible international business conduct; (b) public policymakers, who can be in a better position to formulate policies at the macro level that would guide their indigenous firms to operate in a socially responsible manner in foreign markets; (c) researchers, who can have access to a rich inventory of knowledge that will help to provide the basis for further research on socially responsible issues in international business; and (d) educators, who can transfer to students insights on the socially responsible code of conduct derived from this review to be used in their future business activities as international managers.

The remainder of this chapter is structured as follows. First, we explain the method adopted in this study to undertake the current review. We then present the major contributing journals on socially responsible international business, the most prolific authors on the subject, and the most impactful articles. Following this, we analyze the profiles of the studies reviewed, in terms of research design, scope of research, and study methodology. The next section provides an analysis of the key thematic areas referring to socially responsible international business and the specific issues addressed within each area. The final section draws conclusions from the study findings, offers implications, and suggests directions for future research. 


\subsection{REVIEW APPROACH}

Our review covered all articles on socially responsible international business published in the top eight international business journals, namely Journal of International Business Studies, Journal of World Business, Management International Review, Journal of International Marketing, International Marketing Review, International Business Review, Journal of International Management, and Global Strategy Journal. The review included publications from the inception of this line of research in 1995 up to 2017, which is a sufficiently large period of time from which to derive adequate information on the subject and establish trends. The review covered all types of articles published in these journals, with the exception of editorials, case studies, educational insights, and reply comments.

Eligible articles were identified electronically using various bibliographic databases, such as ABI-INFO, JSTOR, and SCIENCE DIRECT, based on various keywords, such as 'corporate social responsibility', 'responsible business', 'environmental', 'sustainability', 'ethical', 'diversity', 'health and safety', 'corporate citizenship', and so on. Altogether, 163 articles were found relevant for the purposes of our study, while after a thorough examination of their full content, seven articles had to be omitted for lacking real relevance to socially responsible international business issues. The final set of 156 articles comprised conceptual articles (31), empirical articles (114), or review/meta-analysis articles (11). These articles were categorized into three time periods: 1995-2001 (23 articles), 2008-2012 (52 articles), and 2013-2017 (81 articles).

Each of the articles selected was subsequently content analyzed by two experienced researchers, who worked under the supervision of an academic with extensive knowledge of content analysis. Both coders underwent rigorous training in order to understand how to code the information contained in each article. For this purpose, we have developed a coding protocol consisting of three parts: (a) article profile - nature of article, authors' characteristics, number of citations; (b) study characteristics - scope of research, research design, and study methodology; and (c) thematic areas - where a list of items was initially produced by reviewing all articles collected, and subsequently grouping them into categories based on indications derived from prior research and/or previous reviews on CSR articles.

The workability of the coding protocol was tested with a small sample of articles, and the instrument employed revealed no particular problems. To increase consistency in interpreting the information extracted from the articles, a special manual was prepared, incorporating operational definitions for each item that had to be analyzed. The two coders worked 
independently and transferred the information contained in each article onto the coding protocol. Inter-coder reliability tests for each item used revealed an agreement of 91 percent to 95 percent between the two coders, which reflects satisfactory levels. All discrepancies identified were resolved with the assistance of the supervisor, while the data extracted from the completed coding protocols were unified into a common database and subsequently used for descriptive statistical analysis.

\subsection{MAJOR CONTRIBUTING JOURNALS, PROLIFIC AUTHORS, AND KEY ARTICLES}

Table 1.1 shows the contribution of socially responsible international business articles by each of the eight international business journals reviewed. Collectively, there was a significant growth of articles published in these journals, indicating a growing interest by both scholars and journal editors in investigating corporate social responsibility issues within an international business context, from three articles in 1995 to 21 articles

Table 1.1 Journal article contribution to research on socially responsible international business

\begin{tabular}{|c|c|c|c|c|}
\hline \multirow[t]{2}{*}{ Journals } & \multirow{2}{*}{$\begin{array}{c}\text { Total } \\
(\mathrm{n}=156) \\
\%\end{array}$} & \multicolumn{3}{|c|}{ Time period } \\
\hline & & $\begin{array}{c}1995-2007 \\
\left(\mathrm{n}_{1}=23\right) \\
\%\end{array}$ & $\begin{array}{c}2008-2012 \\
\left(\mathrm{n}_{2}=52\right) \\
\%\end{array}$ & $\begin{array}{c}2013-2017 \\
\left(\mathrm{n}_{3}=81\right) \\
\%\end{array}$ \\
\hline Journal of World Business a & 26.3 & 26.1 & 28.8 & 24.7 \\
\hline $\begin{array}{l}\text { International Marketing } \\
\text { Review }^{\text {a }}\end{array}$ & 19.9 & 21.7 & 17.3 & 21.0 \\
\hline $\begin{array}{c}\text { Journal of International } \\
\text { Business Studies a }\end{array}$ & 16.0 & 43.5 & 9.6 & 12.3 \\
\hline $\begin{array}{l}\text { International Business } \\
\text { Review a }\end{array}$ & 14.7 & - & 11.5 & 21.0 \\
\hline $\begin{array}{l}\text { Journal of International } \\
\text { Management }{ }^{\text {a }}\end{array}$ & 9.0 & 8.7 & 17.3 & 3.7 \\
\hline $\begin{array}{l}\text { Management International } \\
\text { Review }\end{array}$ & 6.4 & - & 9.6 & 6.2 \\
\hline $\begin{array}{l}\text { Journal of International } \\
\text { Marketing }\end{array}$ & 4.5 & - & 3.8 & 6.2 \\
\hline Global Strategy Journal & 3.2 & - & 1.9 & 4.9 \\
\hline
\end{tabular}

Note: a Journals with special issues on the topic during the period 1995-2017. 
in 2017. Notably, this interest on the subject is documented by the fact that the time period under examination was marked by the publication of eight special issues, as follows: International Marketing Review (Carrigan, Marinova, and Szmigin, 2005; Ghauri, Park, and Oh, 2015, 2016), Journal of World Business (Mort 2010; Shapiro, Hobdari, and Oh, 2018), Journal of International Business Studies (Rodriguez et al., 2006), International Business Review (Kolk and van Tulder, 2010), and Journal of International Management (Egri and Ralston, 2008). The three top contributing journals were the Journal of World Business (41 articles), International Marketing Review (31 articles), and Journal of International Business Studies (25 articles), accounting for approximately two-thirds (63.2 percent) of the total articles reviewed. However, there were changes over time regarding the publication contribution of these journals. For example, while there was a downward trend of articles on socially responsible international business published in the Journal of International Business Studies, the reverse was observed in the case of International Business Review (which was responsible for publishing 21.0 per cent of the articles during the period 2013-2017).

Altogether, the 156 articles on socially responsible international business covered by our review were written by 404 scholars, that is, on average .38 articles per author. Notably, the top ten authors were responsible for writing 35 (i.e., 22.4 percent) of these articles, which denotes that most scholars have only sporadically published articles on this topic during the time period under investigation (see Table 1.2). Most (4) of the prolific authors were based in the UK, while the remainder were located in the USA (3), South Korea (1), the Netherlands (1), and Cyprus (1). In the case of two contributors, namely Timothy M. Devinney and Constantine S. Katsikeas, these have a current affiliation with the University of Leeds, while the remaining authors had no connection as regards their institutional affiliation. The top three authors in the field, based on their total individual contributions to socially responsible international business articles, were the following, in descending order: Ans Kolk (9), Bryan W. Husted (4), and Leonidas C. Leonidou (4). With regard to the adjusted number of publications (where the number of authors in each article is taken into consideration), the order of the top three contributors is as follows: Ans Kolk (3.66), Bryan W. Husted (2.33), and Yadong Luo (2.33). Finally, based on Google Scholar citations, the three most influential scholars in the field are: Petra Christmann (1,380 citations), Ans Kolk (1,367 citations), and Bryan W. Husted (732 citations).

Based on Google Scholar citations, we have identified the 15 most influential socially responsible international business articles published during the period 1995-2017 (see Table 1.3). With the exception of two 
Table 1.2 Most prolific authors of socially responsible international business articles

\begin{tabular}{|c|c|c|c|c|c|}
\hline Author & University & Country & $\begin{array}{l}\text { Absolute } \\
\text { number of } \\
\text { articles }\end{array}$ & $\begin{array}{l}\text { Adjusted } \\
\text { number of } \\
\text { articles }\end{array}$ & $\begin{array}{l}\text { Google } \\
\text { Scholar } \\
\text { citations }\end{array}$ \\
\hline 1. Ans Kolk & $\begin{array}{l}\text { University of } \\
\text { Amsterdam } \\
\text { Business School }\end{array}$ & $\begin{array}{l}\text { The } \\
\text { Netherlands }\end{array}$ & 9 & 3.66 & 1367 \\
\hline $\begin{array}{l}\text { 2. Bryan W. } \\
\text { Husted }\end{array}$ & $\begin{array}{l}\text { EGADE Business } \\
\text { School }\end{array}$ & USA & 4 & 2.33 & 732 \\
\hline $\begin{array}{l}\text { 3. Leonidas C. } \\
\text { Leonidou }\end{array}$ & $\begin{array}{l}\text { University of } \\
\text { Cyprus }\end{array}$ & Cyprus & 4 & 1.03 & 172 \\
\hline $\begin{array}{l}\text { 4. Timothy M. } \\
\text { Devinney }\end{array}$ & University of Leeds & UK & 3 & 2.25 & 168 \\
\hline $\begin{array}{l}\text { 5. Petra } \\
\text { Christmann }\end{array}$ & Rutgers University & USA & 3 & 1.33 & 1380 \\
\hline $\begin{array}{l}\text { 6. Jonatan } \\
\text { Pinkse }\end{array}$ & $\begin{array}{l}\text { University of } \\
\text { Manchester }\end{array}$ & UK & 3 & 1.33 & 285 \\
\hline 7. Byung Il Park & $\begin{array}{l}\text { Hankuk University } \\
\text { of Foreign Studies }\end{array}$ & South Korea & 3 & 1.16 & 129 \\
\hline 8. Yadong Luo & $\begin{array}{l}\text { University of } \\
\text { Miami }\end{array}$ & USA & 3 & 2.33 & 343 \\
\hline $\begin{array}{l}\text { 9. Pervez N. } \\
\text { Ghauri }\end{array}$ & $\begin{array}{l}\text { University of } \\
\text { Birmingham }\end{array}$ & UK & 3 & 1.00 & 96 \\
\hline $\begin{array}{l}\text { 10. Constantine } \\
\text { S. Katsikeas }\end{array}$ & University of Leeds & UK & 3 & 0.83 & 57 \\
\hline
\end{tabular}

Note: The total number of contributors is 404 from 156 socially responsible international business articles.

articles, all the remaining articles were published from 2006 onwards. Twelve of these articles have an empirical status, two are of a conceptual nature, and one is a review paper. Nine of the articles were published in the Journal of International Business Studies (the premier journal in international business), while the remaining articles appeared in Journal of World Business (3), International Business Review (1), and Journal of International Management (1). In descending order, the five most-cited socially responsible international business articles in the period under review were the following: Peredo and McLean (2006), reviewing the concept of social entrepreneurship (1,434 citations); Maignan and Ralston (2002), examining corporate social responsibility self-presentations (1,324 citations); Weerawardena and Mort (2006), providing a multidimensional model of social entrepreneurship (1,045 citations); Christmann and Taylor (2001), 
Table 1.3 Most influential socially responsible international business articles

\begin{tabular}{|c|c|c|c|c|}
\hline & Authors & Title & Journal & $\begin{array}{l}\text { Google } \\
\text { Scholar } \\
\text { citations }\end{array}$ \\
\hline 1. & $\begin{array}{l}\text { Peredo and } \\
\text { McLean (2006) }\end{array}$ & $\begin{array}{l}\text { Social entrepreneurship: A critical } \\
\text { review of the concept }\end{array}$ & JWB & 1434 \\
\hline 2. & $\begin{array}{l}\text { Maignan and } \\
\text { Ralston (2002) }\end{array}$ & $\begin{array}{l}\text { Corporate social responsibility in } \\
\text { Europe and the US: Insights from } \\
\text { businesses' self-presentations }\end{array}$ & JIBS & 1324 \\
\hline 3. & $\begin{array}{l}\text { Weerawardena } \\
\text { and Mort (2006) }\end{array}$ & $\begin{array}{l}\text { Investigating social entrepreneurship: } \\
\text { A multidimensional model }\end{array}$ & JWB & 1045 \\
\hline 4. & $\begin{array}{l}\text { Christmann and } \\
\text { Taylor (2001) }\end{array}$ & $\begin{array}{l}\text { Globalization and the environment: } \\
\text { Determinants of firm self-regulation } \\
\text { in China }\end{array}$ & JIBS & 905 \\
\hline 5. & $\begin{array}{l}\text { Husted and } \\
\text { Allen (2006) }\end{array}$ & $\begin{array}{l}\text { Corporate social responsibility in the } \\
\text { multinational enterprise: Strategic } \\
\text { and institutional approaches }\end{array}$ & JIBS & 630 \\
\hline 6. & $\begin{array}{l}\text { Waldman et al. } \\
(2006)\end{array}$ & $\begin{array}{l}\text { Cultural and leadership predictors } \\
\text { of corporate social responsibility } \\
\text { values of top management: A } \\
\text { GLOBE study of } 15 \text { countries }\end{array}$ & JIBS & 571 \\
\hline 7. & $\begin{array}{l}\text { Christmann and } \\
\text { Taylor (2006) }\end{array}$ & $\begin{array}{l}\text { Firm self-regulation through } \\
\text { international certifiable } \\
\text { standards: Determinants of } \\
\text { symbolic versus substantive } \\
\text { implementation }\end{array}$ & JIBS & 458 \\
\hline 8. & $\begin{array}{l}\text { Linnenluecke } \\
\text { and Griffiths } \\
(2010)\end{array}$ & $\begin{array}{l}\text { Corporate sustainability and } \\
\text { organizational culture }\end{array}$ & JWB & 424 \\
\hline 9. & $\begin{array}{l}\text { Strike, Gao, and } \\
\text { Bansal (2006) }\end{array}$ & $\begin{array}{l}\text { Being good while being bad: Social } \\
\text { responsibility and the international } \\
\text { diversification of US firms }\end{array}$ & JIBS & 412 \\
\hline 10. & $\begin{array}{l}\text { Rodriguez et al. } \\
(2006)\end{array}$ & $\begin{array}{l}\text { Three lenses on the multinational } \\
\text { enterprise: Politics, corruption, } \\
\text { and corporate social responsibility }\end{array}$ & JIBS & 406 \\
\hline 11. & $\begin{array}{l}\text { Darnall, } \\
\text { Henriques, and } \\
\text { Sadorsky (2008) }\end{array}$ & $\begin{array}{l}\text { Do environmental management } \\
\text { systems improve business } \\
\text { performance in an international } \\
\text { setting? }\end{array}$ & JIMAN & 363 \\
\hline 12. & $\begin{array}{l}\text { Kolk and van } \\
\text { Tulder (2010) }\end{array}$ & $\begin{array}{l}\text { International business, corporate } \\
\text { social responsibility and sustainable } \\
\text { development }\end{array}$ & IBR & 334 \\
\hline
\end{tabular}


Table 1.3 (continued)

\begin{tabular}{llcc}
\hline \multicolumn{1}{c}{ Authors } & Title & Journal & $\begin{array}{c}\text { Google } \\
\text { Scholar } \\
\text { citations }\end{array}$ \\
\hline $\begin{array}{l}\text { 13. Van Tulder and } \\
\text { Kolk (2001) }\end{array}$ & $\begin{array}{l}\text { Multinationality and corporate } \\
\text { ethics: Codes of conduct in the } \\
\text { sporting goods industry }\end{array}$ & JIBS & 320 \\
$\begin{array}{llll}\text { 14. Ioannou and } \\
\text { Serafeim (2012) }\end{array}$ & $\begin{array}{l}\text { What drives corporate social } \\
\text { performance? The role of nation- } \\
\text { level institutions } \\
\text { Green and competitive? An empirical } \\
\text { test of the mediating role of } \\
\text { environmental innovation strategy }\end{array}$ & JWB & 2570 \\
\hline
\end{tabular}

Note: Citation data were gathered during the period 1530th January 2018. JIBS $=$ Journal of International Business Studies; JWB = Journal of World Business; JIMAN = Journal of International Management $; \mathrm{IBR}=$ International Business Review.

focusing on the determinants of company self-regulation with regard to environmental issues (905 citations); and Husted and Allen (2006), dealing with strategic and institutional issues of MNEs' corporate social responsibility (630 citations). Five of these most influential articles focused on corporate social responsibility in general, four articles were concerned with environmental/sustainability issues, two articles paid particular attention to social entrepreneurship, two articles referred to self-regulations imposed by firms themselves in their international business operations, one article focused on ethical issues, while another article concentrated on the firm's social performance.

\subsection{PROFILES OF STUDIES}

\subsubsection{Research Design}

Table 1.4 presents the research design of studies focusing on socially responsible international business. With regard to problem crystallization, the majority ( 48.7 percent) of these studies employed a formalized approach (as opposed to an exploratory perspective), usually expressed in the form of testable research hypotheses. This has become more evident in more recent studies, where more than half (i.e., 56.8 percent) had a formalized structure, indicating the existence of adequate material to build on 
Table 1.4 Research design of socially responsible international business articles

\begin{tabular}{|c|c|c|c|c|}
\hline \multirow[t]{2}{*}{ Research design } & \multirow{2}{*}{$\begin{array}{c}\text { Total } \\
(\mathrm{n}=156) \\
\%\end{array}$} & \multicolumn{3}{|c|}{ Time period } \\
\hline & & $\begin{array}{c}1995-2007 \\
\left(\mathrm{n}_{1}=23\right) \\
\%\end{array}$ & $\begin{array}{c}2008-2012 \\
\left(\mathrm{n}_{2}=52\right) \\
\%\end{array}$ & $\begin{array}{c}2013-2017 \\
\left(\mathrm{n}_{3}=81\right) \\
\%\end{array}$ \\
\hline \multicolumn{5}{|l|}{ Problem crystallization } \\
\hline Exploratory & 24.4 & 26.1 & 25.0 & 23.5 \\
\hline Formalized & 48.7 & 30.4 & 33.2 & 56.8 \\
\hline Non-empirical & 26.9 & 43.5 & 30.8 & 19.8 \\
\hline \multicolumn{5}{|l|}{ Topical scope } \\
\hline Statistical study & 51.9 & 43.5 & 42.3 & 60.5 \\
\hline Case study & 5.8 & - & 13.5 & 2.5 \\
\hline Interview & 13.5 & 13.0 & 9.6 & 16.0 \\
\hline Other & 1.9 & - & 3.8 & 1.2 \\
\hline Non-empirical & 26.9 & 43.5 & 30.8 & 19.8 \\
\hline \multicolumn{5}{|l|}{ Time emphasis } \\
\hline Cross-sectional & 64.1 & 47.8 & 65.4 & 67.9 \\
\hline Longitudinal & 4.5 & 4.3 & 3.8 & 4.9 \\
\hline Other & 4.5 & 4.3 & - & 7.4 \\
\hline Non-empirical & 26.9 & 43.5 & 30.8 & 19.8 \\
\hline \multicolumn{5}{|l|}{ Variable association } \\
\hline Descriptive & 38.5 & 29.1 & 40.4 & 37.0 \\
\hline Causal & 34.6 & 17.4 & 28.8 & 43.2 \\
\hline Non-empirical & 26.9 & 43.5 & 30.8 & 19.8 \\
\hline \multicolumn{5}{|l|}{ Theoretical underpinning a } \\
\hline Institutional Theory & 25.6 & 4.4 & 21.2 & 34.6 \\
\hline Stakeholder Theory & 19.9 & 8.7 & 15.4 & 25.9 \\
\hline RBV or NRBV & 7.7 & 8.7 & 9.6 & 6.2 \\
\hline Legitimacy Theory & 3.8 & - & 9.6 & 1.2 \\
\hline Agency Theory & 3.2 & 4.4 & 3.9 & 2.5 \\
\hline Transaction Cost Theory & 3.2 & 4.4 & 1.9 & 3.7 \\
\hline Other & 24.3 & 17.4 & 23.1 & 27.2 \\
\hline No theory & 35.9 & 56.5 & 40.4 & 28.4 \\
\hline
\end{tabular}

Note: a Studies may refer to more than one category.

other scholars' work. The topical scope of this field of research seems to be dominated by statistical studies (i.e., 51.9 percent) - especially in more recent research, as opposed to qualitative research which usually took the form of case study analysis, in-depth interviews, or focus group discussions. 
Notably, only a few studies employed a mixed method approach, combining both quantitative with qualitative research, although this could provide more insights into the subject. With regard to time emphasis, most (i.e., 64.1 percent) of the studies were cross-sectional in nature, providing only a snapshot of the research problem at a given point in time. On the contrary, the use of longitudinal research was very limited, and this was particularly the case with studies using secondary databases. None of the articles reviewed which employed primary research examined socially responsible international business issues over a long period of time, probably due to time and cost constraints. In terms of variable association, empirical articles were more or less divided into those adopting a descriptive and a causal approach. The latter was more profound in articles having a model-building method and these were primarily connected with formalized research. Interestingly, about a third (i.e., 35.9 percent) of the articles reviewed were not anchored on a specific theory or paradigm and their absence was more evident during the initial phases of this line of research. Of the remainder, Institutional Theory and Stakeholder Theory were the dominant theoretical perspectives (especially in more recent studies), reported in 25.6 percent and 19.9 percent of the articles respectively. Other theories used on a less frequent basis were the Resource-based View (and its modified version of Natural Resource-based View), Legitimacy Theory, Agency Theory, and Transaction Cost Theory.

\subsubsection{Scope of Research}

Table 1.5 provides an overview of the scope of research conducted on socially responsible international business issues. With regard to the number of countries covered by studies in this line of research, about a third (i.e., 30.8 percent) focused on one country only, while another third (i.e., 32.1 percent) included three or more countries in their analysis. Notably, multiple countries were mainly the object of studies aiming to compare the pattern of this phenomenon on a cross-cultural basis. Both Europe (particularly countries in the European Union) and Asia (particularly China) were the focus regions for this research, with each representing 37.2 percent of the total studies reviewed. North America was the third most widely investigated region (i.e., 32.7 percent), while Latin America, Africa, and Oceania received much less attention. With regard to industry coverage, only about a quarter (i.e., 23.1 percent) of the studies concentrated on a single industry, while another quarter (i.e., 25.0 percent) included in their analysis four industries or more. In the latter case, there was a tendency to focus on industries that were more exposed to societal matters, such as those relating to petroleum, mining, and chemicals. Also, an upward trend 
Table 1.5 Scope of research in socially responsible international business articles

\begin{tabular}{|c|c|c|c|c|}
\hline \multirow[t]{2}{*}{ Scope of research } & \multirow{2}{*}{$\begin{array}{c}\text { Total } \\
(\mathrm{n}=156) \\
\%\end{array}$} & \multicolumn{3}{|c|}{ Time period } \\
\hline & & $\begin{array}{c}1995-2007 \\
\left(\mathrm{n}_{1}=23\right) \\
\%\end{array}$ & $\begin{array}{c}2008-2012 \\
\left(\mathrm{n}_{2}=52\right) \\
\%\end{array}$ & $\begin{array}{c}2013-2017 \\
\left(\mathrm{n}_{3}=81\right) \\
\%\end{array}$ \\
\hline \multicolumn{5}{|l|}{ Number of countries } \\
\hline One & 30.8 & 40.4 & 25.0 & 34.6 \\
\hline Two & 9.6 & 4.3 & 7.7 & 12.3 \\
\hline Three or more & 32.1 & 21.7 & 34.6 & 33.3 \\
\hline Not specified & 0.6 & - & 1.9 & - \\
\hline Non-empirical & 26.9 & 43.5 & 30.8 & 19.8 \\
\hline \multicolumn{5}{|l|}{ Focus region $^{\mathrm{a}}$} \\
\hline North America & 32.7 & 30.4 & 28.8 & 35.8 \\
\hline Latin America & 16.0 & 4.3 & 19.2 & 17.3 \\
\hline Europe & 37.2 & 26.1 & 40.4 & 38.3 \\
\hline Asia & 37.2 & 17.4 & 30.8 & 46.9 \\
\hline Africa & 12.2 & - & 11.5 & 16.0 \\
\hline Oceania & 10.9 & 8.7 & 11.5 & 11.1 \\
\hline Other & 6.4 & - & - & 12.3 \\
\hline Not specified & 1.3 & - & 1.9 & 1.2 \\
\hline Non-empirical & 26.9 & 43.5 & 30.8 & 19.8 \\
\hline \multicolumn{5}{|l|}{ Industry coverage } \\
\hline One industry & 23.1 & 4.3 & 36.5 & 19.8 \\
\hline Two industries & 1.9 & 4.3 & 1.9 & 1.2 \\
\hline Three industries & 5.1 & - & 1.9 & 8.6 \\
\hline Four industries or more & 25.0 & 30.4 & 17.3 & 28.5 \\
\hline Not specified & 9.6 & 13.0 & 11.5 & 19.8 \\
\hline Not applicable & 1.9 & - & 2.5 & 1.9 \\
\hline Non-empirical & 26.9 & 43.5 & 30.8 & 19.8 \\
\hline \multicolumn{5}{|l|}{ Unit of analysis a } \\
\hline Firm & 46.8 & 43.5 & 40.4 & 51.9 \\
\hline Consumer & 9.0 & 4.3 & 5.8 & 12.3 \\
\hline Student & 2.6 & - & 5.8 & 2.5 \\
\hline Website/Report/Ad & 9.0 & 4.3 & 17.3 & 4.9 \\
\hline Country & 3.8 & 4.3 & - & 6.2 \\
\hline Other & 5.1 & - & 1.9 & 2.5 \\
\hline Non-empirical & 26.9 & 43.5 & 30.8 & 19.8 \\
\hline
\end{tabular}

Note: a Studies may refer to more than one category. 
was observed to cover multiple industries in articles published during the period 2013-2017. In the majority of cases (i.e., 46.8 percent), the unit of analysis was the individual firm, primarily multinational corporations or exporting/importing companies. Another tenth (i.e., 9.0 percent) obtained data from consumers and in some cases from students. Corporate websites, annual reports, and advertisements provided the unit of analysis for another tenth (i.e., 9.0 percent) of the studies reviewed, with their use being more evident during the period 2008-2012. Finally, a small proportion of studies (i.e., 3.8 percent) carried out their analysis at the country level, aiming to identify differences on how socially responsible international business is practiced on an aggregate level by indigenous firms.

\subsubsection{Study Methodology}

Table 1.6 shows the methodological aspects of studies on socially responsible international business. With regard to sampling design, the majority (i.e., 40.4 percent) of the articles had samples characterized by a non-probability nature, and this was particularly evident in more recent publications. Probability samples were more rarely employed and the same is also true with regard to studies covering the whole population. About two-fifths (i.e., 40.4 percent) of the articles reviewed used sample sizes having less than 250 units, while 17.9 percent reported samples in excess of 500 (often found in studies using secondary data). About a tenth (i.e., 10.3 percent) of the articles had a response rate of less than 30 percent, while in only 4.5 percent of them the response rate was 40 percent or more. With regard to data collection methods, a quarter (i.e., 25.0 percent) of the articles used secondary data in their analysis, and this was more obvious among studies conducted during recent years. In-depth interviews were employed in studies reported in 17.9 percent of the articles, while the survey questionnaire was the most popular data collection method, usually based on mail questionnaires (13.5 percent), drop-in questionnaires (7.7 percent), and electronic questionnaires (7.1 percent). As expected, the latter were more extensively used in more recent research due to the widespread use of the internet. In terms of analytical approaches, in the majority of cases (i.e., 37.8 percent of the articles) multivariate statistical methods were employed, especially structural equation modeling, hierarchical and probit regression analyses, and hierarchical linear modeling. Univariate/ bivariate statistical analysis and descriptive statistics were more rarely used, while modeling approaches were particularly evident in studies conducted in recent years. Our review revealed that there was a low tendency among scholars in the field to control for various types of bias. Specifically, only 12.8 percent of the articles reported that there was a control for 
Table 1.6 Study methodology in socially responsible international business articles

\begin{tabular}{lcccc}
\hline Study methodology & Total & \multicolumn{3}{c}{ Time period } \\
\cline { 2 - 5 }$(\mathrm{n}=156)$ & $\begin{array}{c}1995-2007 \\
\%\end{array}$ & $\begin{array}{c}2008-2012 \\
\left(\mathrm{n}_{1}=23\right)\end{array}$ & $\begin{array}{c}2013-2017 \\
\left(\mathrm{n}_{2}=52\right)\end{array}$ & $\left(\mathrm{n}_{3}=81\right)$ \\
$\%$ & $\%$ & $\%$ \\
\hline
\end{tabular}

Sampling design

Probability

Non-probability

9.6

3.0

5.8

11.1

Whole population

40.4

26.1

40.4

44.4

Not specified

6.4

4.3

9.6

4.9

Non-empirical

16.7

13.0

13.5

19.8

26.9

43.5

30.8

19.8

Sample size

99 or less

100-249

21.8

17.4

21.2

23.5

250-499

18.6

21.7

21.2

16.0

12.8

8.7

9.6

16.0

500 or more

17.9

8.7

11.5

24.7

Not specified

Not applicable

1.3

.6

Non-empirical

26.9

$-$

3.8

1.9

43.5

30.8

19.8

Response rate

19 percent or less

1.3

4.3

1.2

20-29 percent

9.0

8.7

15.4

4.9

4.5

8.7

6.2

4.5

$-$

1.

7.4

9.0

4.3

7.7

11.1

44.9

30.4

44.2

49.4

26.9

43.5

30.8

19.8

Data collection $^{\text {a }}$

Mail questionnaire

13.5

7.1

17.4

9.6

14.8

Electronic questionnaire

4.3

1.9

11.1

Drop-in questionnaire

7.7

4.3

9.6

7.4

Mall-intercept

1.9

3.8

1.2

questionnaire

In-depth interviews

17.9

13.0

21.2

17.3

1.3

$-$

1.9

1.2

Secondary

25.0

13.0

21.2

30.9

Not specified

4.5

4.3

5.8

3.7

26.9

43.5

30.8

19.8

Analytical approach $^{\mathrm{a}}$

Descriptive statistics

Uni-/bivariate

7.1

6.4
17.4

17.4
9.6

2.5

3.8

4.9 
Table 1.6 (continued)

\begin{tabular}{lcccc}
\hline Study methodology & $\begin{array}{c}\text { Total } \\
(\mathrm{n}=156)\end{array}$ & \multicolumn{3}{c}{ Time period } \\
\cline { 3 - 5 } & $\%$ & $\begin{array}{c}1995-2007 \\
\left(\mathrm{n}_{1}=23\right)\end{array}$ & $\begin{array}{c}2008-2012 \\
\left(\mathrm{n}_{2}=52\right)\end{array}$ & $\begin{array}{c}2013-2017 \\
\left(\mathrm{n}_{3}=81\right) \\
\%\end{array}$ \\
\hline Multivariate & & 26.1 & 30.8 & 45.7 \\
Modeling & 37.8 & - & 7.7 & 11.1 \\
Qualitative & 8.3 & 13.0 & 21.2 & 18.5 \\
Other & 18.6 & - & 5.8 & 1.2 \\
Non-empirical & 2.6 & 43.5 & 30.8 & 19.8 \\
Controlling for bias & 26.9 & & & \\
Non-response bias & & 4.3 & 9.6 & 17.3 \\
Endogeneity bias & 12.8 & - & 1.9 & 2.5 \\
Key informant bias & 1.9 & - & 1.9 & 2.5 \\
Common method bias & 1.9 & 8.7 & 11.5 & 18.5 \\
Social desirability bias & 4.7 & - & 7.7 & 3.7 \\
Not applicable & 39.7 & 21.7 & 40.4 & 44.4 \\
Non-empirical & 26.9 & 43.5 & 30.8 & 19.8 \\
\hline
\end{tabular}

Note: a Studies may refer to more than one category.

non-response bias, while the existence of key informant bias was rarely examined (reported in only 1.9 percent of the articles). Common method bias was evaluated in 14.7 percent of the articles reviewed, with the testing of this type of bias showing an upward trend over time. Controlling for endogeneity bias was negligible, as this was examined in only 1.9 percent of the articles. The same was also true with regard to social desirability bias, which was reported in only 4.5 percent of the articles.

\subsection{KEY THEMATIC AREAS}

Throughout the 23-year period examined, research on socially responsible international business has taken many and diverse courses of thematic development, with each gradually examining a variety of topics (see Table 1.7). The content of the articles reviewed was categorized into 49 thematic areas, which fell into ten broad groups as follows: external pressures for being socially responsible (6); marketing strategy and social responsibility (6); performance outcomes of socially responsible practices (6); internationalization aspects of social responsibility (7); types of focal 
Table 1.7 Key thematic areas in socially responsible international business research

\begin{tabular}{|c|c|c|c|c|}
\hline \multirow[t]{2}{*}{ Thematic areas } & \multirow{2}{*}{$\begin{array}{c}\text { Total } \\
(\mathrm{n}=156) \\
\%\end{array}$} & \multicolumn{3}{|c|}{ Time period } \\
\hline & & $\begin{array}{c}1995-2007 \\
(\mathrm{n} 1=23) \\
\%\end{array}$ & $\begin{array}{c}2008-2012 \\
(\mathrm{n} 2=52) \\
\%\end{array}$ & $\begin{array}{c}2013-2017 \\
\text { (n3 = 81) } \\
\%\end{array}$ \\
\hline External pressures for $S R$ & 25.6 & 26.1 & 19.2 & 29.6 \\
\hline Cultural environment & 9.0 & 4.3 & 5.8 & 12.3 \\
\hline $\begin{array}{l}\text { Economic and regulatory } \\
\text { environment }\end{array}$ & 18.6 & 26.1 & 15.4 & 18.5 \\
\hline Media pressures & 1.9 & 4.3 & - & 2.5 \\
\hline Industry pressures & 5.8 & - & 1.9 & 9.9 \\
\hline Customer pressures & 5.8 & 8.7 & 1.9 & 7.4 \\
\hline Other & 10.9 & 4.3 & 7.7 & 13.6 \\
\hline Marketing strategy and $S R$ & 25.6 & 17.4 & 26.9 & 27.2 \\
\hline Promotional strategy & 3.8 & - & 7.7 & 2.5 \\
\hline $\begin{array}{l}\text { Product development } \\
\text { considerations }\end{array}$ & 7.1 & 8.7 & 5.8 & 7.4 \\
\hline $\begin{array}{l}\text { Channel management and } \\
\text { distribution }\end{array}$ & 5.1 & 8.7 & - & 7.4 \\
\hline Price considerations & 1.3 & - & - & 2.5 \\
\hline Overall strategy & 7.1 & - & 7.7 & 8.6 \\
\hline Other & 8.3 & 8.7 & 9.6 & 7.4 \\
\hline $\begin{array}{l}\text { Performance outcomes of } S R \\
\text { practices }\end{array}$ & 24.4 & - & 25.0 & 30.9 \\
\hline Financial performance & 4.5 & - & 5.8 & 4.9 \\
\hline Market performance & 4.5 & - & 3.8 & 6.2 \\
\hline Social performance & 3.2 & - & 3.8 & 3.7 \\
\hline Environmental performance & 3.2 & - & 1.9 & 4.9 \\
\hline Export performance & 4.5 & - & 1.9 & 7.4 \\
\hline Other & 9.0 & - & 7.7 & 12.3 \\
\hline Internationalization aspects of $S R$ & 22.4 & 21.7 & 21.2 & 23.5 \\
\hline Standardization/adaptation & 6.4 & 8.7 & 5.8 & 6.2 \\
\hline Internationalization & 6.4 & 13.0 & 1.9 & 7.4 \\
\hline HQ-Subsidiary relations & 3.8 & - & 3.8 & 4.9 \\
\hline Country distance & 1.3 & - & 3.8 & - \\
\hline Country of origin aspects & 1.9 & - & 1.9 & 2.5 \\
\hline Foreign direct investment & 2.6 & - & 1.9 & 3.7 \\
\hline Other & 2.6 & - & 1.9 & 3.7 \\
\hline Types of focal SR practices & 21.2 & 39.1 & 19.2 & 17.3 \\
\hline Base of the pyramid & 4.5 & - & - & 8.6 \\
\hline $\begin{array}{l}\text { Cause-related marketing/ } \\
\text { philanthropy }\end{array}$ & 1.9 & - & 1.9 & 2.5 \\
\hline
\end{tabular}


Table 1.7 (continued)

\begin{tabular}{|c|c|c|c|c|}
\hline \multirow[t]{2}{*}{ Thematic areas } & \multirow{2}{*}{$\begin{array}{c}\text { Total } \\
(\mathrm{n}=156) \\
\%\end{array}$} & \multicolumn{3}{|c|}{ Time period } \\
\hline & & $\begin{array}{c}1995-2007 \\
(\mathrm{n} 1=23) \\
\%\end{array}$ & $\begin{array}{c}2008-2012 \\
(\mathrm{n} 2=52) \\
\%\end{array}$ & $\begin{array}{c}2013-2017 \\
(\mathrm{n} 3=81) \\
\%\end{array}$ \\
\hline Sustainable development & 1.3 & - & - & 2.5 \\
\hline Social entrepreneurship & 3.2 & 8.7 & 1.9 & 2.5 \\
\hline Fair trade & 1.3 & 8.7 & - & - \\
\hline Working conditions & 3.8 & - & 7.7 & 2.5 \\
\hline $\begin{array}{l}\text { Environmental management } \\
\text { systems }\end{array}$ & 4.5 & 17.4 & 3.8 & 1.2 \\
\hline Other & 3.8 & 4.3 & 7.7 & 1.2 \\
\hline $\begin{array}{l}\text { Internal company influences on } \\
S R\end{array}$ & 19.2 & 8.7 & 19.2 & 22.2 \\
\hline Organizational factors & 7.7 & 4.3 & 7.7 & 8.6 \\
\hline $\begin{array}{l}\text { Managerial characteristics/ } \\
\text { attitudes }\end{array}$ & 8.3 & - & 7.7 & 11.1 \\
\hline Organizational culture & 8.3 & - & 7.7 & 11.1 \\
\hline Other & 1.9 & - & - & 3.7 \\
\hline Communication of $S R$ practices & 14.1 & 13.0 & 23.1 & 8.6 \\
\hline CSR/sustainability reporting & 9.0 & 4.3 & 13.5 & 7.4 \\
\hline Websites & 1.3 & 4.3 & 1.9 & - \\
\hline Advertisements & 1.9 & 4.3 & 3.8 & - \\
\hline Other & 1.9 & - & 3.8 & 1.2 \\
\hline $\begin{array}{l}\text { Foreign consumer behavior toward } \\
S R\end{array}$ & 12.2 & 4.3 & 11.5 & 14.8 \\
\hline Consumer attitudes & 7.7 & 4.3 & 1.9 & 12.3 \\
\hline Consumer motivations & 1.9 & - & - & 3.7 \\
\hline Consumer responses & 7.7 & - & 11.5 & 7.4 \\
\hline Other & - & - & - & - \\
\hline $\begin{array}{l}\text { Stimuli and barriers to } S R \\
\text { adoption }\end{array}$ & 8.3 & 21.7 & 5.8 & 6.2 \\
\hline $\begin{array}{l}\text { Stimuli/incentives to SR } \\
\text { adoption }\end{array}$ & 8.3 & 21.7 & 5.8 & 6.2 \\
\hline $\begin{array}{l}\text { Barriers/disincentives to SR } \\
\text { adoption }\end{array}$ & 2.6 & 8.7 & 1.9 & 1.2 \\
\hline Other & - & - & - & - \\
\hline Miscellaneous & 12.8 & 13.0 & 11.5 & 13.6 \\
\hline
\end{tabular}

Note: Articles could focus on more than one thematic area. 
socially responsible practices (8); internal company influences on social responsibility (4); communication of socially responsible practices (4); foreign consumer behavior toward social responsibility (4); stimuli and barriers to social responsibility adoption (3); and miscellaneous (1). The specific issues addressed in each of these thematic areas are discussed in the following.

The first category refers to external pressures for the international firm to take socially responsible actions, identified in a quarter (i.e., 25.6 percent) of the articles reviewed. In fact, the investigation of this category has intensified during the period 2013-2017. Here, the emphasis was mainly on pressures imposed by the firm's foreign economic and regulatory environment, which was the object of 18.6 percent of the articles. Other external issues that draw scholarly attention were related to pressures exerted by the foreign cultural environment (9.0 percent of the articles), the industry (5.8 percent of the articles), and the customers (5.8 percent of articles), which have also been more widely studied in recent years. Pressures on the firm's activities were also exerted by mass media and/or social media, although this was reported in only 1.9 percent of the articles reviewed. Other issues were also examined in this category, such as complying with technical standards and obtaining certification from independent bodies, with each, however, being the object of a few articles only.

Issues relating to the socially responsible character of the firm's international marketing strategy also attracted a quarter (i.e., 25.6 percent) of the articles, and again the study of this area showed growth trends over time. Specifically, 7.1 percent of the articles focused on the overall marketing strategy as a whole, while of the elements of the marketing mix, product development considerations and channel distribution/management received most attention (tackled by 7.1 percent and 5.1 percent of the articles respectively). Conversely, pricing and promotional issues, although often confronted with ethical dilemmas, were less frequently investigated.

The performance implications of the firm's socially responsible international business practices were the focus of 24.4 percent of the articles reviewed, reaching an even higher level (i.e., 30.9 percent) during the period 2013-2017. Notably, the thrust of the emphasis was on market performance and financial performance, each reported in 4.5 percent of the articles. Another 4.5 percent of the articles connected the firm's socially responsible actions in foreign markets with its export performance. Also, 3.4 percent of the articles studied the impact of socially responsible international business on more specialized aspects of performance, such as social performance and environmental performance. A sizeable number of articles, representing 9.0 percent of the total, included a variety of other performance measures. 
Another important thematic area, tackled by 22.4 percent of the articles reviewed, refers to various internationalization aspects of the firm's socially responsible behavior. The emphasis here was to examine whether international firms standardize or adapt this behavior across countries (reported by 6.4 percent of the articles), while the same emphasis was put on understanding how the firm's social responsibility changes at different stages of the internationalization process. Other issues examined on a less frequent basis focused on how the firm's socially responsible activities are affected by the relationships between headquarters and their subsidiaries (3.8 percent of the articles), the nature of the foreign direct investment (2.6 percent of the articles), the firm's country of origin (1.9 percent of the articles), and the distance between the home and host country (1.3 percent of the articles).

More than a fifth (i.e., 21.2 percent) of the articles focused on various types of socially responsible international business areas, with the most common being based on the pyramid issues and environmental management systems (each tackled by 4.5 percent of the articles). However, although the former was an issue widely studied in recent years, the opposite was true with regard to the latter. The nature of the working conditions for producing the MNEs' products in foreign markets was the object of 3.8 percent of the articles reviewed, while the study of social entrepreneurship in an international context was examined in 3.2 percent of the articles. Other corporate social responsibility issues which received less attention were cause-related marketing and philanthropy (1.9 percent), sustainable development (1.3 percent), and fair trade (1.3 percent).

The role of internal company influences on shaping the firm's socially responsible practices in international markets was reported by 19.2 percent of the articles reviewed, with the number of articles on this thematic area growing sharply over time. Three major issues received more or less the same attention here (each tackled by around 8 percent of the articles), namely the nature of the organizational culture (e.g., a commitment toward social values), various organizational determinants (e.g., availability of financial resources), and specific characteristics or attitudes of top managers (e.g., personal sensitivity to social issues). Notably, research interest in all three issues experienced an increasing tendency over time.

About a seventh (i.e., 14.1 percent) of the articles reviewed delved into the communications aspects of the firm's socially responsible practices abroad, with studies conducted during the period 2008-2012 showing greater interest in this thematic area. The dominant topic here dealt with by researchers was the reporting of the CSR/sustainability achievements of international firms, reported in 9.0 percent of the articles. An analysis of advertisements promoting the socially responsible character of these 
firms was observed in another 1.9 percent of the articles, while an exploration of this issue in corporate websites received much less attention (i.e., 1.3 percent of the articles).

Another stream of research, which rose from 4.3 percent in the period 1995-2007 to 14.8 percent in the period 2013-2017, and averaged 12.2 percent of the articles during the whole period under investigation, referred to foreign consumer behavior toward social responsibility. The focus was on foreign consumer attitudes (e.g., likeness, beliefs, and feelings and responses (e.g., boycotting, product/store preferences, and purchasing decisions/choices) toward the international firm's socially responsible activities, each reported by 7.7 percent of the articles). A few articles (i.e., 1.9 percent of the total) focused on specific consumer motivations, such as tangible and intangible product attributes, attributions, and value systems.

The final thematic area revolved on factors pushing or preventing international firms to adopt socially responsible practices in foreign markets, traced in 8.3 percent of the articles reviewed. However, although this area was highly researched during the initial phases of the investigation period, it has gradually faded over time. Stimuli/incentives to adopt international socially responsible activities (e.g., corporate aspirations/ orientation, financial rewards, international diversification) attracted most of the attention, while barriers/disincentives to social responsibility adoption (e.g., financial constraints, market access limitations, production constraints) were recorded in only a few articles (i.e., 2.6 percent).

\subsection{CONCLUSIONS, IMPLICATIONS, AND FUTURE DIRECTIONS}

One central conclusion that can be derived from the previous review of the literature on socially responsible international business is that this body of research, although relatively limited in quantity, has advanced remarkably during the last decades (particularly in recent years). Driving forces behind these developments were studies that appeared in specific publication outlets specializing in international business, as well as a group of prolific researchers who were responsible for a large percentage of the total articles published on the subject. The work of these scholars has been the source of many influential ideas that encouraged other current or neophyte scholars to produce more studies. Our review has also identified certain articles that have greatly influenced academic thinking on socially responsible international business and laid the foundations for the further advancement of this research. 
With regard to research design, it seems that this field of research is gradually becoming more mature, as demonstrated by the increasing use of formalized approaches, the adoption of more statistical studies, and the extensive theoretical grounding provided. However, there is still room for more causal type of research to be conducted and the execution of longitudinal studies. The scope of research has also shown signs of proliferation, as indicated by the increasing use of multi-country studies, the coverage of diverse industries, and the variety of angles of units of analysis used to examine the subject matter. However, there is still room for improvement, especially as regards the conduct of more research in emerging and developing economies, particularly focusing on unexplored regions like Latin America and Africa. In the case of methodological issues, this line of research is characterized by adequate sample sizes, reasonable response rates, and strong analytical tools, although there is a space to employ more probability samples. There is also a need to make more extensive use of various bias controls with regard to survey non-response, common method variance, endogeneity, and social desirability.

With regard to the thematic areas covered, both the breadth and depth of research on socially responsible issues have increased over time, taking ideas mainly from management, marketing, operations management, and human resource management. All in all, this body of knowledge has applied a social responsibility flavor to almost all aspects of international business activity, ranging from internationalization and buyer behavior to strategic issues and performance outcomes. Thematic focus varied by time period, with some topics showing declining trends (e.g., stimuli and barriers to social responsible adoption), others demonstrating upward trends (e.g., performance implications of socially responsible activities), while still others exhibit an unclear developmental pattern (e.g., communication of social responsible achievements).

\subsubsection{Implications}

Despite serious developments in this line of research, there is still room to advance it further through more collaborative efforts among international business scholars. It is also important to encourage doctoral students and neophyte researchers to conduct research on novel research projects on socially responsible international business. New ideas can be borrowed from recent developments in the domestic literature on corporate social responsibility, as well as from studies conducted in other business (e.g., marketing) or non-business (e.g., sociology) disciplines. There is also a need to expand the geographic scope of this research, by extending the analysis to cover understudied countries (e.g., developing economies), 
industry groups (e.g., pharmaceuticals), and market type (e.g., business to business).

Journal editors should encourage more research on socially responsible international business issues, especially in crucial areas which have been under-researched, such as the analysis of consumer behavior toward foreign firms' socially responsible or irresponsible activities. Although several special journal issues on the subject have been published in the past, producing many insightful articles, there is still room for more to cover new cutting-edge areas of research. In addition, defining relevant conference session themes, organizing special interest research groups, and setting panel discussions focusing on socially responsible issues would also be helpful to further advance this area of research. The periodic publishing of chapters in edited books will also assist in generating, disseminating, and applying new knowledge on the subject.

\subsubsection{Limitations}

Although an adequate number of socially responsible international articles was found in the top eight international business journals to carry out our review, more articles can also be traced in other specialized (e.g., Journal of Global Marketing) or mainstream (e.g., Academy of Management Journal) business journals. In addition, in our study we excluded monographs, books, edited volumes, and conference proceedings, which can also contain rich input on the subject. Although our data were analyzed in a manual way, it is understood that the use of powerful computer software programs for qualitative analysis (e.g., NVivo, Qualrus, CATPAC) could produce more insights.

Despite the insightful information provided by this review, there is room to extend the analysis to other important issues, such as the epistemological foundations and developments of this line of research, the various conceptualizations of social responsibility used by extant studies, and the nature of causal associations between constructs. With regard to the latter, the application of meta-analytical methods on the empirical results of prior research can provide an integrated picture of the strength, sign, and direction of these associations, particularly on topics where available findings are too fragmented and/or too controversial to yield concrete conclusions.

The findings of this review could be enriched with additional input directly derived from scholars specializing in international business. This could take the form of surveys among academics in different parts of the world and/or focus group discussions with scholars carrying out research on socially responsible international business. The use of the Delphi 
method among researchers would also be useful to generate more ideas on how this stream of research should advance in the future and prioritize the directions to be taken. Finally, forming a specialized 'think tank', comprising prominent researchers in the field, would help to identify cutting-edge areas of research and provide a more systematic and coordinated effort to investigate socially responsible phenomena in international business.

\section{REFERENCES}

Carrigan, M., Marinova, S., and Szmigin, I. (2005). Ethics and international marketing: Research background and challenges. International Marketing Review, 22(5), 481-493.

Christmann, P., and Taylor, G. (2001). Globalization and the environment: Determinants of firm self-regulation in China. Journal of International Business Studies, 32(3), 439-458.

Christmann, P., and Taylor, G. (2006). Firm self-regulation through international certifiable standards: Determinants of symbolic versus substantive implementation. Journal of International Business Studies, 37(6), 863-878.

Darnall, N., Henriques, I., and Sadorsky, P. (2008). Do environmental management systems improve business performance in an international setting? Journal of International Management, 14(4), 364-376.

Demirbag, M., Wood, G., Makhmadshoev, D., and Rymkevich, O. (2017). Varieties of CSR: Institutions and socially responsible behaviour. International Business Review, 26(6), 1064-1074.

Egri, C.P., and Ralston, D.A. (2008). Corporate responsibility: A review of international management research from 1998 to 2007. Journal of International Management, 14(4), 319-339.

Eiadat, Y., Kelly, A., Roche, F., and Eyadat, H. (2008). Green and competitive? An empirical test of the mediating role of environmental innovation strategy. Journal of World Business, 43(2), 131-145.

Eteokleous, P.P., Leonidou, L.C., and Katsikeas, C.S. (2016). Corporate social responsibility in international marketing: Review, assessment, and future research. International Marketing Review, 33(4), 580-624.

Ghauri, P.N., Park, B.I., and Oh, C. H. (2015). Guest editorial. International Marketing Review, 32(5).

Ghauri, P.N., Park, B.I., and Oh, C. H. (2016). Special Issue. International Marketing Review, 33(4).

Grinstein, A., and Riefler, P. (2015). Citizens of the (green) world? Cosmopolitan orientation and sustainability. Journal of International Business Studies, 46(6), 694-714.

Husted, B.W., and Allen, D.B. (2006). Corporate social responsibility in the multinational enterprise: Strategic and institutional approaches. Journal of International Business Studies, 37(6), 838-849.

Ioannou, I., and Serafeim, G. (2012). What drives corporate social performance? The role of nation-level institutions. Journal of International Business Studies, 43(9), 834-864.

Kolk, A., and van Tulder, R. (2010). International business, corporate social 
responsibility and sustainable development. International Business Review, 19(2), $119-125$.

Linnenluecke, M.K., and Griffiths, A. (2010). Corporate sustainability and organizational culture. Journal of World Business, 45(4), 357-366.

Maignan, I., and Ralston, D.A. (2002). Corporate social responsibility in Europe and the US: Insights from businesses' self-presentations. Journal of International Business Studies, 33(3), 497-514.

Mort, G.S. (2010). Sustainable business. Journal of World Business, 45(4), 323-325.

Peredo, A.M., and McLean, M. (2006). Social entrepreneurship: A critical review of the concept. Journal of World Business, 41(1), 56-65.

Pisani, N., Kourula, A., Kolk, A., and Meijer, R. (2017). How global is international CSR research? Insights and recommendations from a systematic review. Journal of World Business, 52(5), 591-614.

Rathert, N. (2016). Strategies of legitimation: MNEs and the adoption of CSR in response to host-country institutions. Journal of International Business Studies, 47(7), 858-879.

Rodriguez, P., Siegel, D., Hillman, A., and Eden, L. (2006). Three lenses on the multinational enterprise: Politics, corruption, and corporate social responsibility. Journal of International Business Studies, 37(6), 733-746.

Shapiro, D., Hobdari, B., and Oh, C. H. (2018). Natural resources, multinational enterprises and sustainable development. Journal of World Business, 53(1), 1-14.

Strike, V. M., Gao, J., and Bansal, P. (2006). Being good while being bad: Social responsibility and the international diversification of US firms. Journal of International Business Studies, 37(6), 850-862.

van Tulder, R., and Kolk, A. (2001). Multinationality and corporate ethics: Codes of conduct in the sporting goods industry. Journal of International Business Studies, 32(2), 267-283.

Waldman, D.A., De Luque, M.S., Washburn, N., House, R.J., Adetoun, B., Barrasa, A., and Dorfman, P. (2006). Cultural and leadership predictors of corporate social responsibility values of top management: A GLOBE study of 15 countries. Journal of International Business Studies, 37(6), 823-837.

Weerawardena, J., and Mort, G.S. (2006). Investigating social entrepreneurship: A multidimensional model. Journal of World Business, 41(1), 21-35.

Zhao, H., Zhang, F., and Kwon, J. (2018). Corporate social responsibility research in international business journals: An author co-citation analysis. International Business Review, 27(2), 389-400. 